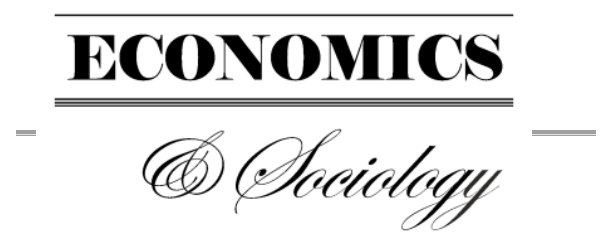

Mihaela Simionescu, Institute for Economic Forecasting of the Romanian Academy, Bucharest, Romania,

E-mail:mihaela_mb1@yahoo.com

Received: May, 2018

1st Revision: August, 2018

Accepted: November, 2018

DOI: $10.14254 / 2071-$

789X.2018/11-4/6

\section{EFFECTS OF EUROPEAN ECONOMIC INTEGRATION ON FOREIGN DIRECT INVESTMENT: THE CASE OF ROMANIA}

\author{
JEL Classification: C51, \\ C53, F21
}

\title{
Introduction
}

Four economic freedoms specific to the internal market are ensured through economic integration: free movement of capital, which includes foreign direct investment (FDI), goods, labour and services. Under economic integration, barriers to trade and international investments are abolished (or at least relaxed) which makes global FDI grow. Transport and communication costs have declined considerably in recent decades, as Dollar (2001) shows. Prices have also been significantly reduced through multilateral negotiations under the General Agreement on Tariffs and Trade (GATT) and through the initiatives of certain countries or groups of states (Clemens \& Williamson, 2002; Gao, 2005). These achievements have allowed multinational companies reduce business costs within firms and between firms, and also manage cross-border production more easily.

Many advantages of European economic integration have been attributed to new member states (more attracted FDI, mobility inside the EU for work, study etc.). However, empirical studies on real data have not been made yet to prove that in reality the new member states have in fact benefited of these advantages. Therefore, the aim of this paper is to check for the real impact of European economic integration on bilateral FDI and on FDI that have been attracted by Romania. The Heckman selection models were proposed for some years 
before and after Romania's integration in the EU. A sample of countries is considered in the analysis as Romanian's partners for FDI.

The paper continues with the presentation of theoretical background on the effects of economic integration on FDI highlighting results from literature. The gravity approach is described and the empirical results are commented. The last part of the paper concludes.

\section{Literature review}

The benefits of European economic integration are not limited to the increasing level of FDI. There are some benefits of European economic integration for EU Member States that directly or indirectly influence FDI: almost unlimited access to EU funds and its markets, available human capital, VAT-free for intra-EU transactions, a stable legal environment, better corridors transport, lower transaction costs in the context of market liberalization and greater competition, etc. The creation of the Single European Market in the late 1980s has removed many internal barriers to investment and cross-border trade. Since the late 1980s, it has been observed that the Single European Market has led many firms in EU countries to increase their investment in other EU countries. However, there is not any theory on FDI to include clear empirical arguments for the effects of liberalization of investment and trade (Brenton et al., 1999).

All these benefits of European economic integration are underpinned by a legislative framework, some regulations existing for EU common policies that promote and protect FDI among the member countries of the Union. Some recent examples in this regard are provided below.

The Treaty of Lisbon, which entered into force in 2009, has allowed the EU's exclusive competences in the area of international trade, including FDI. In the 2010 Communication on "Trade, Growth and International Business", the European Commission is among the pillars of the Europe 2020 strategy and international trade, a more competitive and greener union of states being pursued. The role of trade policy in promoting investment, but also in enhancing economic growth and job creation is also described in the "Trade for All" Strategy developed in 2015.

The European Commission Communication from September 2017 provides a solution for protecting certain FDI categories, guaranteeing EU citizens security and public order measures to eliminate unfair practices. One of the issues raised in this Communication relates to the take-up of firms in the EU, especially when these companies implement strategic activities and technologies.

Even if efforts are made at both EU and national level to attract as much FDI as possible from other EU countries, the way in which regional integration has stimulated FDI attraction or can only be explained on empirical basis. In general, empirical studies explaining the relationship between regional integration and FDI can be grouped into two categories:

- Studies explaining FDI provisions in regional integration agreements and anticipating how these agreements will stimulate FDI attraction (UNCTAD, 1996; Te Velde, 2017);

- Studies based on econometric models explaining FDI based on several independent variables, one of which is a binary variable that confirms / denies the country's membership of a regional agreement (Levy-Yeyati et al., 2002; Altomonte, 2007; Campos \& Coricelli, 2015, Simionescu, 2016, Delevic \& Heim, 2017).

There are numerous provisions whereby regional integration agreements can influence FDI: investment rules, trade rules and other initiatives (Blomström \& Kokko, 1997; Dunning, 1997; Gurbanov et al., 2015; Simionescu, 2016 et al., 2016, 2017, 2018). 
Most studies based on the econometric approach show that extra-regional FDI stimulates FDI, but in some cases intra-regional FDI is also stimulated. Thus, for 60 OECD countries as host countries for FDI, Levy-Yeyati et al. (2003) showed that membership in the same regional agreement led to an increase in the volume of FDI attracted by almost $27 \%$ between 1982-1999. Regional integration, corroborated with market size, is a determining factor for FDI. Other studies focus on other regions: MERCUSOR (Chudnovsky \& Lopez, 2001), NAFTA (Waldkirch, 2003; Feils \& Rahman, 2008) or UNCTAD (2003).

The effects of the European Single Market are assessed by Pain (1997), Pain \& Lansbury (1997), Dunning (1997), Benito et al. (2003), Straathof et al. (2008), Campos \& Coricelli (2015), Delevic \& Heim 2017), especially on econometric grounds.

According to Dunning (1997), the main dynamic impact of European economic integration on FDI is through its effects on FDI determinants, such as: market size, structure of economy, income level, economies of agglomeration. The effects of integration are manifested at industry level, with more FDI attracted outside the EU in industries that attract more FDI than others. There is little evidence that economic activities have geographically focused on the Single Market, although high added-value sectors remain clustered, while sectors with low added value are scattered. There is some complementarity between FDI and trade. Straathof et al. (2008) uses gravitational models to show that the effect of European economic integration was greater on FDI than on trade. EU countries have attracted in average 17\% more intra-regional FDI due to EU membership in 1961-2005. Knowing the bilateral FDI flows for 34 OECD countries between 1985 and 2013, Bruno et al. (2016) have shown that EU membership has boosted FDI flows by $14 \%$ to $38 \%$.

A recent study made by Delevic and Heim (2017) showed that Eastern European countries that became EU member states have attracted more FDI due to their EU membership. The survey considered 16 countries in transition (Romania, Bulgaria, Croatia, Bosnia-Herzegovina, Albania, Czech Republic, Greece, Hungary, Kazakhstan, Serbia, Latvia, Lithuania, Estonia, Montenegro, Slovakia, Slovenia) between 2002 and 2014. Other non-EU countries, such as Kazakhstan, have attracted FDI due to institutional development and internal investment promotion policies.

FDI has risen sharply, even before integration, together with EU enlargement announcements. Thus, inflows of FDI rose sharply in the Czech Republic, Hungary and Poland in 1994 after the announcement made by the European Council of Essen on the integration process of these states into the EU (Beavan \& Estrin, 2000). FDI grew in 1997 in only five Central and Eastern European countries (Poland, Hungary, the Czech Republic, Slovenia, Estonia) due to the formal decision to start procedures for EU accession. There is a series of empirical studies confirming the hypothesis that EU integration has provided more FDI to transition economies (Stosic et al., 2011; Bitzenis \& Vlachos, 2013). Stosic et al. (2011) showed that Romania and Bulgaria attracted more FDI than Serbia immediately after EU accession. Therefore, by accelerating efforts for the EU integration, Serbia can improve its business environment and attract more foreign investors. In the case of Bulgaria, Bitzenis and Vlachos (2013) have shown that the European economic integration is not the single determinant of FDI. The export is also important in attracting FDI.

However, unlike the developed countries, developing countries have attracted a smaller volume of FDI, and further efforts to increase competitiveness through the restructuring of the economy are still needed. In this context, the EU should develop parallel economic policies to reduce the large gaps between EU countries in attracting FDI. Another explanation for the smaller volume of FDI attracted by the new EU Member States is provided by Bellak and Narula (2008). They have shown that globalization has mitigated the benefits of EU membership of new Member States, which should develop policies to attract FDI from other emerging non-EU countries. All the companies should become competitive on 
the Single European Market to boost economic growth and reduce disparities in GDP per capita.

Since joining the EU, Romania has attracted more FDI, creating new jobs, but has also grown economic growth, living standards, saving and investing, ensuring better protection consumers and increasing competition, developing capital markets, etc. All these advantages have also helped attract foreign investors to Romania. Unlike other countries that have recently joined the EU, Romania and Poland have reached the highest level of FDI inflows during the pre-crisis period (2005-2008). This result for Romania is also explained by the acceleration of privatization on the background of preparations for EU integration and by the increased confidence of foreign investors. In 2008, Romania was the 10th EU country according to the attracted FDI volume. After the crisis, however, Romania has not remained a country as attractive as Poland.

The advantages of European economic integration for Romania are counterbalanced by fierce competition with firms in the old EU Member States, the competitive pressures of the Single Market, rapid technological change, which can bring unemployment in the short term as a result of the restructuring of businesses and sectors.

\section{Methodological approach}

Gravity models are used in the economy to manage the large variation in economic interaction in space related to factor and trade mobility. The tractability of this approach is due to modularity: the distribution of factors and goods in space is determined by gravitational forces conditioned by the size of the economic activities in each location. Modularity allows for disaggregation by regions and goods at any scale and allows for inferences on trade costs that do not depend on a particular model of production and on the structure of the market at complete equilibrium.

Traditional gravity model is based on Newton law. The mass of production factors provided at origin $i, Y_{i}$, is attracted by the mass of demand of goods and labour at destination $j, E_{j}$, but potential flow is reduced by the distance between origin and destination, $d_{i j}$.

$$
X_{i j}=\frac{Y_{i} E_{j}}{d_{i j}^{2}}
$$

$X_{i j}$ - anticipated mobility of goods and labour force between $i$ and $j$

A theoretical background of gravity models is presented by Anderson (1979). The author introduces a model where goods are differentiated by country of origin and consumers have preferences for all differentiated products.

In the general formulation, the gravity equation has the following multiplicative form:

$$
X_{i j}=G S_{i} M_{j} \theta_{i j}
$$

$X_{i j}$ - monetary value of exports from $i$ to $j$

$S_{i}$ - exporter-specific factors that aggregate the exporter's total supply, such as the GDP of the exporting country

$M_{j}$ - importer-specific factors that aggregate the importer's total demand, such as the GDP of the importing country

G- variable that does not depend on $i$ and $j$, like trade liberalization

$\theta_{i j}$ - exporter $i$ facility to access the market $j$ 
Starting from the gravity approach, the Heckman (1978) selection model will be applied in empirical applications. The model proposed by Heckman (1978) starts from a regression:

$$
y_{j}=x_{j} \beta+u_{1 j}
$$

The dependent variable is not always observed. The dependent variable for observation $j$ is observed if the condition is fulfilled (selection equation):

$$
z_{j} \gamma+u_{2 j}>0
$$

$\mathrm{z}$ - the variable used to determine if the dependent variable is observable or not

$$
\begin{gathered}
u_{1} \sim N(0, \sigma) \\
u_{2} \sim N(0,1) \\
\operatorname{corr}\left(u_{1}, u_{2}\right)=\rho
\end{gathered}
$$

If $\rho \neq 0$ (correlations between models' errors), then the application of common estimation techniques generates biased estimators. In this case, the Heckman selection regression allows us to obtain asymptotic efficient and consistent estimators.

In this paper, the dependent variable is represented by bilateral FDI and FDI inflows. The explanatory variables are represented by: GDP per capita in constant prices of 2010, American dollars, exports of good and services as percent of GDP, a dummy variable EU_membership that takes the value 1 if the country is EU member state and 0, otherwise.

\section{Empirical results}

Data for GDP per capita and exports are provided by the World Bank. Data on bilateral FDI for Romania and countries in and outside the EU and for FDI inflows are taken from the UNCTAD database. All data cover the period 2005-2016.

Several Heckman selection models were constructed to explain Romania's bilateral FDI in relation to other countries, but also the FDI inflows. The following countries were considered in the period 2005-2016: Austria, Belgium, Bulgaria, Cyprus, France, Germany, Greece, Hungary, Ireland, Italy, Netherlands, Poland, Portugal, Slovakia, Slovenia, Spain, Sweden, UK, Norway, Switzerland, Canada, US, Australia, Japan, Korea, Iran, Iraq, Turkey, Moldavia and Russia.

As expected, the Heckman selection model in Table 1 confirms expectations based on economic theory: exports have a positive and significant influence on bilateral FDI between Romania and other countries. The result is also confirmed by Egger (2001), which shows that FDI and export are determined by the same factors. EU membership of the sample countries has had a positive impact on FDI. The result is in line with that obtained by Barell and Nahhas (2018). The authors showed a strong impact of European economic integration on bilateral FDI between 1995 and 2015 for a sample of OECD countries. The GDP per capita of the countries was not a determinant of FDI in this case. 
Table 1. Heckman selection model for explaining bilateral FDI between Romania and other countries (2005-2016)

\begin{tabular}{|c|c|c|c|c|}
\hline Variable & Coefficient & $\begin{array}{c}\text { Robust standard } \\
\text { error }\end{array}$ & $\mathrm{z}$ & $\mathrm{P}>|\mathrm{z}|$ \\
\hline $\ln$ (exports) & 0.321 & 0.091 & 3.55 & 0.000 \\
\hline constant & -2.477 & 2.306 & -1.07 & 0.283 \\
\hline EU_membership & 0.701 & 0.189 & 3.69 & 0.000 \\
\hline constant & -0.035 & 0.126 & -0.28 & 0.777 \\
\hline athrho & -2.045 & 0.247 & -8.25 & 0.000 \\
\hline $\ln ($ sigma $)$ & 0.883 & 0.093 & 9.43 & 0.000 \\
\hline
\end{tabular}

Source: author's calculations

The models are rebuilt for two distinct periods: 2005-2006, before Romania's accession to the EU and 2007-2012, after Romania's integration into the EU. For the 2005-2006 period, only a Heckman selection model was valid, with the exports coefficient being significant at a significance level of 10\%, as can be seen from Table 2. On the other hand, the coefficient for EU membership was not significant statistically, indicating that prior to joining the EU, Romania did not attract and did not significantly generate more FDI from / to EU countries compared to non-EU countries.

Table 2. Heckman selection model for explaining bilateral FDI between Romania and other countries (2005-2006)

\begin{tabular}{|c|c|c|c|c|}
\hline Variable & Coefficient & $\begin{array}{c}\text { Robust standard } \\
\text { error }\end{array}$ & $\mathrm{Z}$ & $\mathrm{P}>|\mathrm{z}|$ \\
\hline $\ln ($ exports) & 0.331 & 0.184 & 1.79 & 0.073 \\
\hline constant & -4.178 & 4.76 & -0.88 & 0.380 \\
\hline EU_membership & -0.265 & 0.491 & -0.54 & 0.589 \\
\hline constant & 1.182 & 0.411 & 2.87 & 0.004 \\
\hline athrho & 0.462 & 0.765 & 0.60 & 0.545 \\
\hline $\ln ($ sigma $)$ & 0.676 & 0.157 & 4.30 & 0.000 \\
\hline
\end{tabular}

Source: author's calculations

Table 3 shows the Heckman selection model which indicates the positive influence of the EU membership of the partner countries of Romania after this country joined the EU. Therefore, the positive impact of the partner countries from EU in 2005-2012 is explained by the accession of Romania to the EU in 2007.

Table 3. Heckman selection model for explaining bilateral FDI between Romania and other countries (2005-2016)

\begin{tabular}{|c|c|c|c|c|}
\hline Variable & Coefficient & $\begin{array}{c}\text { Robust standard } \\
\text { error }\end{array}$ & $\mathrm{Z}$ & $\mathrm{P}>|\mathrm{z}|$ \\
\hline $\ln$ (exports) & 0.314 & 0.077 & 4.07 & 0.000 \\
\hline constant & -2.105 & 1.901 & -1.11 & 0.268 \\
\hline EU_membership & 0.69 & 0.187 & 3.69 & 0.000 \\
\hline constant & -0.157 & 0.125 & -1.25 & 0.210 \\
\hline athrho & -2.066 & 0.379 & -5.45 & 0.000 \\
\hline $\ln ($ sigma $)$ & 0.883 & 0.098 & 8.99 & 0.000 \\
\hline
\end{tabular}

Source: author's calculations 
Therefore, we can conclude that after Romania's accession to the EU, Romania attracted and made more FDI from / to the EU member countries compared to the period when it was not a member of the EU. The result is in line with the results obtained by Rădulescu and Jianu (2011) and Delevic and Heim (2017), showing the capacity of Romania and other Eastern European countries to attract more FDI after joining the EU on the grounds of improving institutional efficiency.

Other models of the same type were developed to explain the FDI attracted by Romania in 2005-2016, then on sub-periods (2005-2006 and 2007-2012). As expected, the Heckman selection model in Table 4 confirms expectations based on economic theory: exports of the partner countries have a positive and significant influence on FDI attracted by Romania. The result is also confirmed by Egger (2001), who shows that FDI and exports are determined by the same factors. EU membership of the sample countries has had a positive impact on FDI. The result is in line with that obtained by Barell and Nahhas (2018). The authors showed a strong impact of European economic integration on FDI over the period 1995-2015 for a sample of OECD countries.

Table 4. Heckman selection model for explaining FDI inflows in Romania (2005-2016)

\begin{tabular}{lcccc}
\hline Variable & Coefficient & $\begin{array}{c}\text { Robust standard } \\
\text { error }\end{array}$ & $\mathrm{Z}$ & $\mathrm{P}>|\mathrm{z}|$ \\
\hline $\ln ($ exports) & 0.340 & 0.107 & 3.17 & 0.000 \\
\hline constant & -2.879 & 2.802 & -1.03 & 0.304 \\
\hline EU_membership & 0.685 & 0.136 & 5.02 & 0.000 \\
\hline constant & -0.084 & 0.129 & -0.65 & 0.517 \\
\hline athrho & -2.167 & 0.300 & -7.21 & 0.000 \\
\hline $\ln ($ sigma) & 0.980 & 0.074 & 13.21 & 0.000 \\
\hline
\end{tabular}

Source: author's calculations

The model is rebuilt for two distinct periods: 2005-2006, before Romania's accession to the EU and 2007-2012, after Romania's integration into the EU.

For the period 2005-2006, only the Heckman selection model was valid, with the exports coefficient being significant at $10 \%$ significance level, as shown in Table 5. On the other hand, the coefficient for EU membership was not significant statistically, indicating that prior to joining the EU, Romania did not attract significantly more FDI from EU countries compared to non-EU countries.

Table 5. Heckman selection model for explaining FDI inflows in Romania (2005-2006)

\begin{tabular}{lcccc}
\hline Variable & Coefficient & $\begin{array}{c}\text { Robust standard } \\
\text { error }\end{array}$ & $\mathrm{z}$ & $\mathrm{P}>|\mathrm{z}|$ \\
\hline $\ln ($ exports) & 0.330 & 0.123 & 2.68 & 0.007 \\
\hline constant & -2.428 & 3.249 & -0.75 & 0.455 \\
\hline EU_membership & 0.689 & 0.155 & 4.43 & 0.000 \\
\hline constant & -0.213 & 0.147 & -1.45 & 0.148 \\
\hline athrho & -2.186 & 0.370 & -5.90 & 0.000 \\
\hline $\ln ($ sigma $)$ & 0.980 & 0.091 & 10.71 & 0.000 \\
\hline
\end{tabular}

Source: author's calculations

Table 6 shows the Heckman selection model that presents the positive influence of the EU membership of foreign investors in EU countries after Romania joined the EU. Therefore, the positive impact of the EU membership of partner countries in 2007-2016 is explained by the accession of Romania to the EU in 2007. 
Table 6. Heckman selection model for explaining FDI inflows in Romania (2007-2016)

\begin{tabular}{|c|c|c|c|c|}
\hline Variable & Coefficient & $\begin{array}{c}\text { Robust standard } \\
\text { error }\end{array}$ & $\mathrm{z}$ & $\mathrm{P}>|\mathrm{z}|$ \\
\hline $\ln$ (exports) & 0.314 & 0.077 & 4.07 & 0.000 \\
\hline constant & -2.105 & 1.901 & -1.11 & 0.268 \\
\hline EU_membership & 0.69 & 0.187 & 3.69 & 0.000 \\
\hline constant & -0.157 & 0.125 & -1.25 & 0.210 \\
\hline athrho & -2.066 & 0.379 & -5.45 & 0.000 \\
\hline $\ln ($ sigma $)$ & 0.883 & 0.098 & 8.99 & 0.000 \\
\hline
\end{tabular}

Source: author's calculations

Therefore, we can be concluded that, after the EU integration, Romania has attracted more FDI from the EU member countries compared to the period when it was not a member of the EU. The result is in line with the results obtained by Rădulescu and Jianu (2011) and Delevic and Heim (2017), showing the capacity of Romania to attract more FDI after joining the EU due to reforms and improved business environment.

\section{Conclusion}

This paper proved on empirical backgrounds the benefits of EU membership for a country in the Central and Eastern Europe that joined EU in 2007 (Romania). The advantages of free movement of factors is analysed from the perspective of FDI. In this context, we checked if the European economic integration is a relevant determinant for FDI in Romania. Some Heckman selection models were estimated for 2005-2016, providing also estimations for sub-periods (2005-2006 and 2007-2016). GDP per capita of the origin countries of foreign investors was not relevant in explaining the FDI in Romania. It seems that exports have a positive influence on FDI. Countries with more exports are more likely to invest in Romania. According to Helpman et al. (2004), companies with low productivity prefer more to export than to invest in foreign countries, while firms with high productivity prefer to export less and to open businesses in other countries. This aspect reveals details about the type of foreign investors in Romania. It seems that foreign investors are companies with a lower productivity, but they might prefer cheaper labour force from Romania.

However, the models did not include many macroeconomic variables, focusing on a basic gravity approach. In a future research, other potential determinants might be included (distance, language (Latin language or not) etc.).

\section{Acknowledgement}

„This work was supported by a grant of Ministry of Research and Innovation, CNCS UEFISCDI, project number PN-III-P1-1.1-PD-2016-0163, within PNCDI III”.

\section{References}

Altomonte, C. (2007). Regional economic integration and the location of multinational firms. Review of World Economics, 143(2), 277-305.

Barrell, R., \& Willem te Velde, D. (2002). European integration and manufactures import demand: an empirical investigation of ten European countries. German Economic Review, 3(3), 263-293. 
Barrell, R., FitzGerald, J., \& Riley, R. (2007). EU Enlargement and Migration: Assessing the Macroeconomic Impacts, National Institute for Economic and Social Research Discussion Paper No. 292 (London).

Bellak, C., \& Narula, R. (2008). EU enlargement and consequences for FDI assisted industrial development (No. em-dp2008-69). Henley Business School, Reading University.

Benito, G. R., Grøgaard, B., \& Narula, R. (2003). Environmental influences on MNE subsidiary roles: economic integration and the Nordic countries. Journal of International Business Studies, 34(5), 443-456.

Bevan, A. A., \& Estrin, S. (2004). The determinants of foreign direct investment into European transition economies. Journal of comparative economics, 32(4), 775-787.

Bitzenis, A., \& Vlachos, V. A. (2013). Bulgaria's inward FDI and EU accession. Journal of East-West Business, 19(3), 222-236.

Blomstrom, M., \& Kokko, A. (1997). Regional integration and foreign direct investment (No. w6019). National Bureau of Economic Research.

Brenton, P., Di Mauro, F., \& Lücke, M. (1999). Economic integration and FDI: An empirical analysis of foreign investment in the EU and in Central and Eastern Europe. Empirica, 26(2), 95-121.

Brenton, P., Di Mauro, F., \& Lücke, M. (1999). Economic integration and FDI: An empirical analysis of foreign investment in the EU and in Central and Eastern Europe. Empirica, 26(2), 95-121.

Bruno, R., Campos, N., Estrin, S., \& Tian, M. (2016). Technical Appendix to 'The impact of Brexit on foreign investment in the UK'Gravitating towards Europe: an econometric analysis of the FDI effects of EU membership.

Campos, N., \& Coricelli, F. (2015). Some unpleasant Brexit econometrics. VoxEU. org.

Chudnovsky, D., \& López, A. (2001). La inversión extranjera directa en el MERCOSUR: un análisis comparativo. in Daniel Chudnovsky, ed., El Boom de Inversión Directa en el Mercosur (Madrid: Siglo XXI Editoria Iberoamericana), pp. 1-50.

Clemens, M. A., \& Williamson, J. G. (2004). Why did the tariff-growth correlation change after 1950?. Journal of Economic Growth, 9(1), 5-46.

Delevic, U., \& Heim, I. (2017). Institutions in transition: is the EU integration process relevant for inward FDI in transition European economies?. Eurasian Journal of Economics and Finance, 5(1), 16-32.

Dunning, J. H. (1997). The European internal market programme and inbound foreign direct investment. JCMS: Journal of Common Market Studies, 35(2), 189-223.

Feils, D. J., \& Rahman, M. (2008). Regional economic integration and foreign direct investment: The case of NAFTA. Management International Review, 48(2), 147-163.

Gao, T. (2005). Foreign direct investment and growth under economic integration. Journal of international economics, 67(1), 157-174.

Gurbanov, R., Bilan, Y., \& Strielkowski, W. (2015). Economic advantages and disadvantages of Turkish EU accession. Montenegrin Journal of Economics, 11(2), 7-30.

Heckman, J. J. (1978, April). Simple statistical models for discrete panel data developed and applied to test the hypothesis of true state dependence against the hypothesis of spurious state dependence. In Annales de l'INSEE (pp. 227-269). Institut national de la statistique et des études économiques.

Helpman, E., Melitz, M. J., \& Yeaple, S. R. (2004). Export versus FDI with heterogeneous firms. American economic review, 94(1), 300-316.

Levy-Yeyati, E. L., Stein, E., \& Daude, C. (2003). Regional Integration and the Location of FDI. Inter-American Development Bank, mimeo. 
Pain, N. (1997). Continental drift: European integration and the location of UK foreign direct investment. The Manchester School, 65(S), 94-117.

Pain, N., \& Lansbury, M. (1997). Regional economic integration and foreign direct investment: the case of German investment in Europe. National Institute Economic Review, 160(1), 87-99.

Rădulescu, M., \& Jianu, E. (2011). FDIs in Spain after its EU accession. Spanish investments in Romania and how can be used Spanish experience for Romania's development. Annals of the University of Petrosani Economics, 11(2), 233-256.

Simionescu, M. (2016). The impact of BREXIT on the foreign direct investment in the United Kingdom. Bulgarian Economic Papers, 7, 1-18.

Simionescu, M. (2018). The impact of Brexit on the UK inwards FDI. Economics, Management and Sustainability, 3(1), 6-20. doi:10.14254/jems.2018.3-1.1

Simionescu, M., Bilan, Y., Smrčka, L., \& Vincúrová, Z. (2017). The effects of European economic integration and the impact of brexit on the UK immigrants from the CEE countries. E+ M Ekonomie a Management. 20(1), 29-47.

Simionescu, M., Ciuiu, D., Bilan, Y., \& Strielkowski, W. (2016). GDP and net migration in some eastern and south-eastern countries of Europe. A panel data and Bayesian approach. Montenegrin Journal of Economics, 12(2), 161-175

Stošić, I., Nikolić, D., \& Đukić, M. (2011). Attractiveness of Serbia for foreign direct investments: Tendencies, obstacles and perspectives, 47-60. Available online at: http://ebooks.ien.bg.ac.rs/219/1/is_2011_01.pdf .

Straathof, B., Linders, G. J., Lejour, A., \& Jan, M. Ã. (2008). The internal market and the Dutch economy: Implications for trade and economic growth (No. 168). CPB Netherlands Bureau for Economic Policy Analysis.

Te Velde, D. W. (2017). Investment-related provisions in regional trade agreements. In Regional Integration and Poverty (pp. 103-164). Routledge.

UNCTAD (2003). World Investment Report 2003: FDI Policies for Development: National and International Perspectives (New York and Geneva: United Nations).

UNCTAD. (1996). World Investment Report 1996: Investment, Trade and International Policy Arrangements. Foreign Trade Review, 31(3), 85-109. 